\title{
USE OF VASCULAR DOPPLER ULTRASOUND TO DETECT ACUTE ESTRADIOL VASCULAR EFFECT IN POSTMENOPAUSAL WOMEN
}

Ruth Clapauch ${ }^{1,3}$, Tatiana M Mattos ${ }^{1}$, Helena BMP Uchoa ${ }^{1}$, Andrea SR Ferreira ${ }^{1}$, Vinicius G Bonisson ${ }^{1}$, Érika L Lopes ${ }^{1}$, Isabel CS Nascimento ${ }^{2}$, Eliete Bouskela ${ }^{3}$

Clapauch R, Mattos TM, Uchoa HBMP, Ferreira ASR, Bonisson VG, Lopes EL, Nascimento ICS, Bouskela E. Use of vascular doppler ultrasound to detect acute estradiol vascular effect in postmenopausal women. Clinics.2007;62(6):673-8.

OBJECTIVES: To report on a simple practical test for assessing acute estradiol vascular effects on healthy and unhealthy postmenopausal women.

INTRODUCTION: Estradiol acts in the endothelium to promote vasodilatation through genomic and non-genomic mechanisms, but its vascular action may be impaired in diabetes mellitus, hypertension, smoking and obesity.

METHODS: Nineteen postmenopausal women (nine healthy and 10 with two or more of the above factors) of similar age and time since menopause were examined with vascular Doppler ultrasound. Resistance indexes and systolic and diastolic flow velocities were determined for the brachial and internal carotid arteries at baseline and 20 minutes after administration of a nasal estradiol formulation, available on the market, which reaches 1,200-1,500 pg/ml in the serum in 10-30 minutes. Estradiol blood levels were measured at 30 minutes.

RESULTS: The carotid resistance index increased $14.2 \%$ (vasoconstriction) in the unhealthy group after estradiol, from a mean \pm S.E. of $0.56 \pm 0.016$ at baseline to $0.64 \pm 0.05$ ( $\mathrm{p}=0.033$ ), and remained unchanged in healthy women. Brachial diastolic flow velocity increased $19.7 \%$ (vasodilatation) in healthy women, from $16.2 \pm 1.93$ to $19.4 \pm 0.64 \mathrm{~cm} / \mathrm{s}$ ( $\mathrm{p}=0.046$ ), and did not change in the unhealthy subjects. Estradiol levels were similar in both groups.

DISCUSSION: Healthy postmenopausal women showed brachial vasodilatation while unhealthy postmenopausal women displayed vasoconstriction at the carotid artery. Vascular responses to estradiol were divergent between the groups.

CONCLUSIONS: The acute estradiol test, coupled with Doppler ultrasound, seemed to be able to differentiate women with normal and abnormal endothelial function in a simple, non-invasive manner.

KEYWORDS: Hormone replacement therapy. Estrogen. Vascular endothelium. Vasodilatation. Vasoconstriction.

\section{INTRODUCTION}

The cardiovascular benefits of estrogen during menopause are currently controversial. Observational studies have shown a reduction of 40 to $50 \%$ in coronary disease risk in women continuously using hormonal replacement

${ }^{1}$ Female Endocrinology Sector, Hospital da Lagoa, Health Ministry,

${ }^{2}$ EcoDoppler Cardiology Exams and

${ }^{3}$ Laboratório de Pesquisas em Microcirculacão, State University of Rio de

Janeiro, Rio de Janeiro, RJ, Brazil

Email: rclapauch@uol.com.br

Received for publication on April 27, 2007

Accepted for publication on August $\mathbf{1}^{\text {st, }} \mathbf{2 0 0 7}$ therapy from the onset of menopause ( 8.5 to 20 years $^{1,2}$ ). On the other hand, in the prospective randomized, doubleblind Women's Health Initiative (WHI) study, women who received estrogen + progesterone therapy ${ }^{3}$ had an increased risk of cardiovascular events after 5.2 years of treatment (RR 1.29). In women using only estrogen therapy (ET), the reduction of cardiovascular risk was not significant (RR 0.91) after seven years. ${ }^{4}$ It should be noted, however, that the WHI study recruited women with a mean age of 63 years; that is, 13 years after the onset of menopause and with a great prevalence of associated pathologies, such as arterial hypertension, diabetes mellitus and obesity. The 
possible existence of a "window of opportunity" for estrogen for cardiovascular protection during menopause has been suggested. ${ }^{5}$ In 1996, Clarkson ${ }^{6}$ demonstrated that estrogen was able to promote primary prevention of arteriosclerosis in female monkeys when administered immediately after oophorectomy. Later, the same author observed a total loss of this benefit if ET was postponed for the equivalent of six years in women. ${ }^{7}$

The window of opportunity could be connected to vascular endothelium integrity, the main site of estradiol's cardioprotection mechanisms. ${ }^{8}$ Estradiol's influences on the endothelium are complex. ${ }^{9}$ The vasomotor effect depends upon a genomic action on $\beta$-estrogen receptors, which activate nitric oxide $(\mathrm{NO})$ synthase and consequently increase $\mathrm{NO}$ production, thus modulating vasoreactivity. Increased $\mathrm{NO}$ production elicits vasodilatation in arteries with a normal endothelium and might attenuate or even abolish it in arteries with endothelial dysfunction. ${ }^{10,11}$ Estradiol also acts on endothelium and vascular smooth muscle cell calcium channels, promoting a short-lasting vasodilatation immediately after its administration. Estradiol treatment inhibits voltagedependent type $2 \mathrm{Ca}^{++}$channels and controls $\mathrm{K}^{+}$flow through the membrane, opening voltage-activated cAMP-dependent $\mathrm{K}^{+}$and $\mathrm{Ca}^{++}$channels. This action has recently been demonstrated, and is mediated by $\alpha$-estrogen receptors present in smooth muscle cells of the coronary vascular wall. ${ }^{12}$

Several risk factors implicated in the pathophysiology of cardiovascular diseases, such as smoking, arterial hypertension, dyslipidemia and diabetes mellitus, have endothelial dysfunction as a common denominator ${ }^{13-15}$ with predominant vasoconstrictor activity and a reduction of NO biological activity, implicating increased vascular vulnerability.

The question we have tried to answer is this: how can one evaluate in a simple and practical way if the endothelium is healthy and can respond to estrogen, with potential cardiovascular benefit, in postmenopausal women? To answer this question, we developed a test to evaluate vascular reactivity using vascular Doppler ultrasound and explored the acute effects of a new $17 \beta$-estradiol formulation for nasal administration. Ten to 30 minutes after its application, serum levels of estradiol reach a peak of 1,200 to $1,500 \mathrm{pg} / \mathrm{dl}$, values much greater than the maximum values found during menacme ( $400 \mathrm{pg} / \mathrm{dl})$. Such high levels rapidly fall, but with estrogen receptor saturation, the genomic effect persists for 24 hours and is comparable to other forms of hormonal replacement. ${ }^{16}$

Here we describe a pilot study of this test. The objectives of the present work were to verify if acute vascular response to high levels of estradiol were different in healthy versus unhealthy women and if the test could be useful for vascular evaluation during menopause.

\section{MATERIALS AND METHODS}

Nineteen women from the Menopause Clinic currently using hormone therapy for climacteric syndrome were selected based on their records and according to the following criteria: spontaneous (at least one year of amenorrhea) or surgical (hysterectomy with bilateral oophorectomy) menopause; age less than 60 years; healthy (group I), without any known cardiovascular risk factor $(n=9)$, or unhealthy (group II), with two or more risk factors, such as hypertension, diabetes mellitus, obesity and smoking, but without any previous cardiovascular event, such as myocardial infarction, angina pectoris or stroke $(n=10)$.

Arterial hypertension was defined by two separate measures of blood pressure higher than $140 / 90 \mathrm{mmHg}$ or by a previous diagnosis when the woman was using anti-hypertensive therapy. Diabetes mellitus was confirmed by two separate determinations of fasting glucose higher than 126 $\mathrm{mg} / \mathrm{dl}$ or by a previous diagnosis when the patient was using an oral hypoglycemic agent. Obesity was defined when the body mass index (BMI, mass in $\mathrm{kg}$ divided by the squared height in meters) was higher than 30 .

Exclusion criteria were hypertension not well controlled by medication $(>160 / 100 \mathrm{mmHg})$, hyper- or hypothyroidism and use of medication that could interfere in the test with acute estradiol, such as calcium channel blockers, sulfonylureas, corticoids and drugs with actions on the central nervous system.

Patients that agreed to participate in the study had an appointment made in the afternoon at the ultrasound clinic. They were told not to use hormonal replacement therapy, any medication with action on the central nervous system or alcohol 40 hours prior to the Doppler exam. It was also asked that they did not eat, consume drinks that contained caffeine (coffee, black tea or soda with coca) or smoke for two hours before the exam.

In the clinic, before the procedure, every step of the study was explained to participants and they signed a written informed consent, per the protocol approved by the Institutional Review Board.

The blood pressures of the participants were measured with a Tycos apparatus within $5 \mathrm{~min}$ of their arrival and three times during a period of $30 \mathrm{~min}$, with the lowest value recorded considered to be the baseline value. During these measurements, the participants were kept in the waiting room, seated, in a relative restful and calm environment. After at least $30 \mathrm{~min}$, basal vascular ultrasound (ATL HDI 3000, coupled with a probe of $7.5 \mathrm{MHz}$ ) was performed. The following parameters were analyzed in the brachial and internal carotid arteries at an identical angle (not greater than $60^{\circ}$ ): resistance index (RI, to infer changes in vascular di- 
ameter) and systolic (SF) and diastolic (DF) flow velocities.

After these measurements, the patients returned to the waiting room and received $150 \mu \mathrm{g}$ of $17 \beta$-estradiol through a nasal spray in each nostril (total of $300 \mu \mathrm{g}$ ) and had their blood pressure measured 10, 20 and 30 min afterward. A second vascular ultrasound was made within 20 min after nasal administration of $17 \beta$-estradiol and the same parameters of the first exam were evaluated. Vasodilatation was inferred from a decrease in RI and/or an increase in DF, and vasoconstriction was inferred from the opposite results (an increased RI and/ or a decreased DF). After the last blood pressure measurement, blood was collected to quantify serum levels and prove the absorption of $17 \beta$-estradiol by the nasal route.

\section{Statistical analysis}

To evaluate if the groups could be compared, means and proportions were made using the paired t-test or $\chi^{2}$, as applicable. Fischer's exact test was used when there were restrictions on the use of $\chi^{2}$. The effects of nasal estradiol on blood pressure and on Doppler vascular responses were analyzed using the GLM procedure for repeated measurements, according to the SPSS package, version 12, which allows for comparison of more than two series (e.g., control time, 10, 20 and $30 \mathrm{~min}$ ) with the influence of other variables, such as age and menopausal time. Results were considered significantly different for $\mathrm{p}<0.05$.

\section{RESULTS}

No significant difference could be found between healthy and unhealthy women for age (control mean \pm S.D. $50.6 \pm$ 8.5 and unhealthy group $52.0 \pm 4.8$ years, $\mathrm{p}=0.65)$, age when menopause occurred $(44.1 \pm 7.8$ versus $44.5 \pm 6.2$ years, respectively, $\mathrm{p}=0.91$ ) or time elapsed since menopause $(6.4 \pm 3.5$ versus $7.5 \pm 5.0$ years, respectively, $p=0.61)$. For each group, five women were hysterectomized and oophorectomized and used only transdermal estrogen; the others used transdermal estrogen associated with cyclical dihydrogesterone.

Among unhealthy women, the most prevalent morbidity was hypertension (10/10), followed by diabetes mellitus $(7 / 10)$, obesity (3/10) and smoking (3/10). In this group, three women had three risk factors for cardiovascular disease, and the others had two.

The mean BMI \pm S.D. for the healthy group was 26.2 $\pm 3.0 \mathrm{~kg} / \mathrm{m}^{2}$, which is characteristic of being overweight, but none were obese $(\mathrm{BMI}>30)$. On the other hand, in the unhealthy group, there were three obese patients, but the mean BMI was not statistically different from that observed for the healthy group $\left(29.8 \pm 4.9 \mathrm{~kg} / \mathrm{m}^{2}, \mathrm{p}=0.078\right)$.
No significant change in blood pressure could be detected during the whole procedure. Mean estradiol levels 30 min after nasal administration were similar for both groups: $581 \pm 378$ (healthy group) and $575 \pm 194 \mathrm{pg} / \mathrm{ml}$ (unhealthy group, $\mathrm{p}=0.967$ ).

The Doppler ultrasound measurements at baseline were not different between the groups, but the carotid resistance index and brachial diastolic flow velocity responses to estradiol were divergent. For healthy women, there was no change in the carotid RI, from a mean \pm S.E of $0.60 \pm 0.023$ at baseline to $0.56 \pm 0.02$ after estradiol $(p=0.48)$. However, for the unhealthy group, the carotid RI increased $14.2 \%$ after estradiol, from $0.56 \pm 0.016$ at baseline to 0.64 $\pm 0.05(\mathrm{p}=0.033)$. Carotid RI variation after estradiol is shown in Figure 1. There was an opposite response between healthy and unhealthy women $(\mathrm{p}=0.028)$.

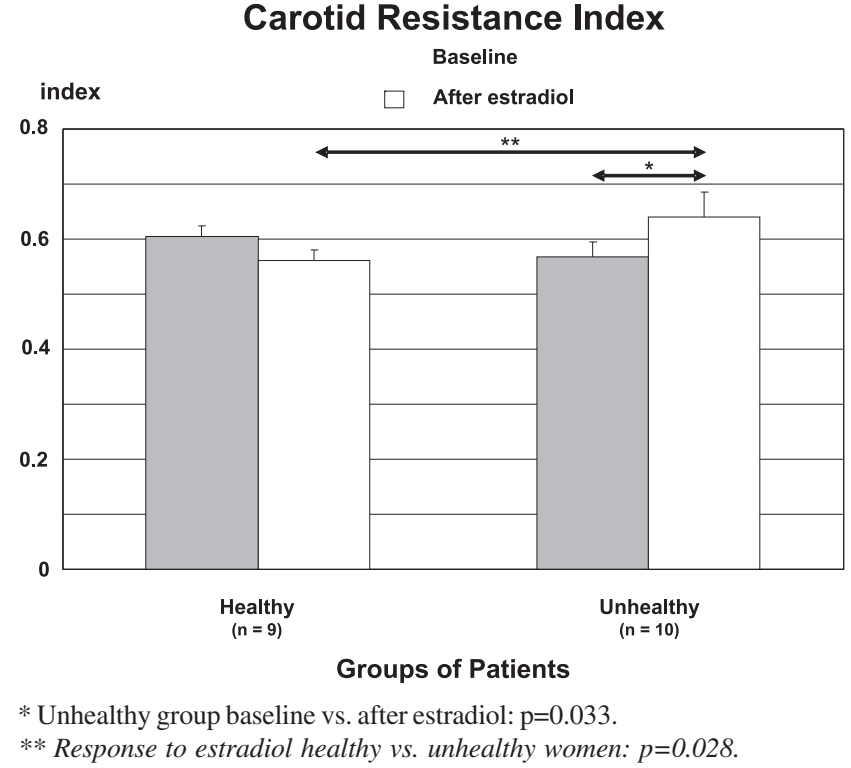

Figure 1 - Carotid resistance index before and 20 min after nasal administration of $300 \mu \mathrm{g}$ of $17 \beta$-estradiol in healthy and unhealthy women.

Diastolic flow velocity increased $19.7 \%$ at the brachial artery in the healthy group after estradiol treatment (from a mean \pm S.E of $16.2 \pm 1.93$ to $19.4 \pm 0.64 \mathrm{~cm} / \mathrm{s}, \mathrm{p}=0.046)$. For the unhealthy group, brachial DF did not change (17.7 \pm 1.63 to $16.7 \pm 1.83, \mathrm{p}=0.314)$. Brachial $\mathrm{DF}$ variation after estradiol is represented in Figure 2. The response was almost significantly different between the two groups $(\mathrm{p}=0.055)$.

No differences in systolic flow velocity, brachial RI or carotid DF could be detected in the two groups after estradiol. At the carotid artery, the SF of healthy women changed from a mean \pm S.E of $52.2 \pm 2.7$ to $54.0 \pm 2.1$ $\mathrm{cm} / \mathrm{s}$. The carotid $\mathrm{SF}$ in unhealthy women varied from 58.9 \pm 4.7 to $58.9 \pm 4.6 \mathrm{~cm} / \mathrm{s}(\mathrm{p}=0.820$ for the response to estradiol for both groups and $\mathrm{p}=0.682$ for the response in 


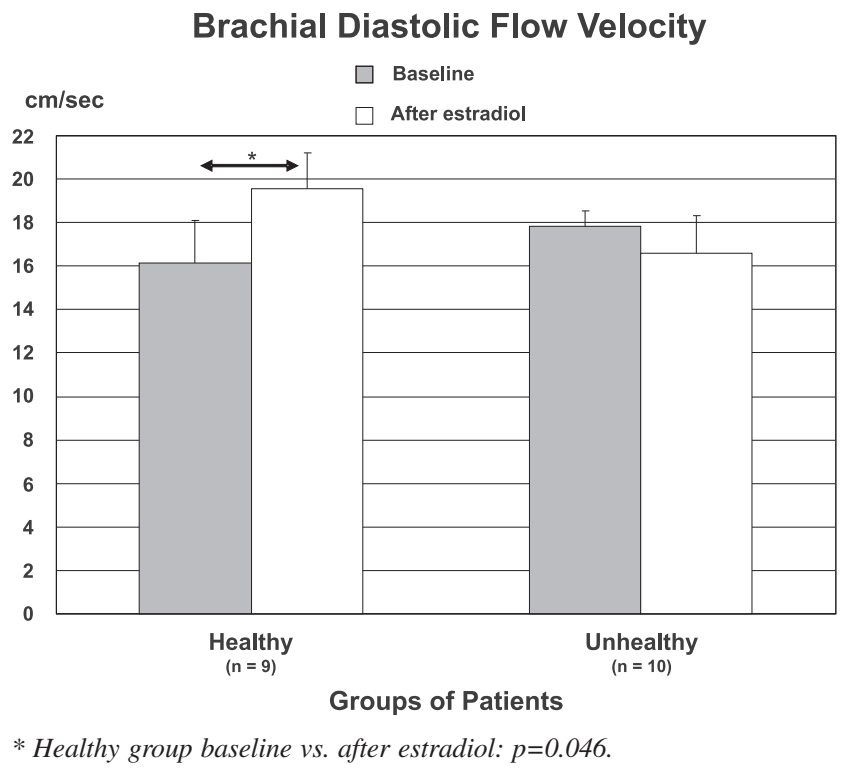

Figure 2 - Brachial diastolic blood flow velocity $(\mathrm{cm} / \mathrm{s})$ before and $20 \mathrm{~min}$ after nasal administration of $300 \mu \mathrm{g}$ of $17 \beta$-estradiol in healthy and unhealth women.

each group, healthy and non-healthy). At the brachial artery, the SF of healthy women changed from $66.5 \pm 5.35$ to $73.5 \pm 6.1 \mathrm{~cm} / \mathrm{s}$ and the SF of unhealthy women changed from $62.2 \pm 4.7$ to $58.4 \pm 6.4 \mathrm{~cm} / \mathrm{s}$ after estradiol ( $\mathrm{p}=0.06$ for response to estradiol for both groups and 0.084 for response in each group).

\section{DISCUSSION}

After acute administration of $17 \beta$-estradiol, healthy postmenopausal women showed increased brachial artery DF (vasodilatation) and unhealthy ones showed increased carotid artery resistance (vasoconstriction).

The mechanisms of estrogen vascular action include NO production and $\mathrm{Ca}^{++}$channel blockade. The final effect depends on the endothelium integrity and elasticity (degree of stiffness) of the arterial wall. Our results suggest that healthy postmenopausal women, i.e., without risk factors for cardiovascular disease, showed the vasodilator effect at the brachial artery expected after nasal administration of $17 \beta$-estradiol, which possibly correlates with better vascular function at the endothelial layer and better elasticity of the vascular wall.

Several other studies have confirmed beneficial effects from estrogen by different administration pathways (oral, transdermic or intranasal) on vascular resistance in healthy women. ${ }^{17-19}$ Zegura and co-workers ${ }^{17}$ reported that oral or transdermal estradiol replacement for a period of 28 weeks improved the endothelial function of middle-aged healthy women six weeks after surgical menopause. In this study, endothelium-dependent and -independent dilatation was evaluated by measuring the brachial artery diameter with high resolution Doppler ultrasound at rest, after reactive hyperemia and following administration of sublingual nitrate. Endothelium-dependent vasodilatation increased after oral (from $6.0 \pm 3.9 \%$ to $13.2 \pm 4.4 \%, \mathrm{p}<0.001$ ) and transdermal (from $7.0 \pm 4.9 \%$ to $14.9 \pm 5.7 \%, \mathrm{p}<0.001$ ) estradiol administration. Endothelium-independent vasodilatation did not change.

Acar and co-workers, ${ }^{18}$ in an experimental, randomized, placebo-controlled, double-blinded cross-over study, evaluated the acute effect of nasal $17 \beta$-estradiol on cerebral blood flow, as measured by Doppler ultrasound, on 18 healthy $42-58$ year old women after natural menopause occurring $3.6 \pm 2.6$ years previously. There was a significant increase in internal carotid and vertebral artery and cerebral blood flow compared with placebo. The study concluded that this effect could protect against cerebral atrophy and dementia and improve cognitive function.

Lima $^{19}$ investigated the effect of an acute, sublingual, therapeutic/low dose of $17 \beta$-estradiol on seven postmenopausal women with mild hypertension (diastolic pressure 90$110 \mathrm{mmHg}$ and systolic pressure $140-180 \mathrm{mmHg}$ ) and no other cardiovascular risk factors. Diabetes mellitus, dyslipidemia and smoking were exclusion criteria and mean BMI was $25 \mathrm{~kg} / \mathrm{m}^{2}$. Eight normotensive women of similar ages and BMI served as controls. Forearm blood flow (FBF) was measured during intrabrachial infusion of increasing doses of acetylcholine and sodium nitroprusside, before and after $1 \mathrm{mg}$ of sublingual $17 \beta$-estradiol. Before estradiol application, FBF was similar for both groups. After administration, FBF significantly improved for increasing doses of acetylcholine in both groups (normotensives, maximal response: $17.6 \pm 5.0$ versus $22.5 \pm 7.0 \mathrm{ml} / \mathrm{min} / 100 \mathrm{ml}$ and hypertensives: $11.0 \pm 4.0$ versus $16.0 \pm 6 ; 12.0 \pm 4.0$ versus $17.0 \pm 5.0$ and $14.0 \pm 3.0$ versus $20.0 \pm 7.0 \mathrm{ml} / \mathrm{min} / 100 \mathrm{ml}$ ). Acute administration of $17 \beta$-estradiol did not change the dose-response curve for sodium nitroprusside in either group. The authors concluded that these women, with mild arterial hypertension but without other cardiovascular risk factors, still had an estrogen-responsive endothelium.

In our study, the carotid RI response to acute administration of $17 \beta$-estradiol was different in healthy and unhealthy postmenopausal women. Unhealthy women showed significant vasoconstriction of the carotid artery after $17 \beta$ estradiol treatment, suggesting that their arteries were already damaged, either at the endothelial layer or at the vascular wall itself (reduction of elasticity). We selected a distinct group of women, with at least two cardiovascular risk factors impairing endothelial function, in order to better demonstrate if there was a different vascular response to acutely high levels of estradiol compared to controls. Fac- 
tors such as hypertension, diabetes mellitus, smoking and obesity can damage endothelial cells, leading to endothelial dysfunction, impaired NO production and increased reactive oxygen species (ROS) production, with clinical consequences such as vasospasm, thrombosis and/or arteriosclerosis. The latter deteriorates arterial wall elasticity through accumulation of smooth muscle cells and $\mathrm{Ca}^{++}$, contributing to increased arterial wall stiffness. Increased stiffness and parietal thickness, present in advanced arteriosclerosis, could limit maximum vasodilatation of an artery.

White and co-workers, ${ }^{20}$ in an experimental study with porcine endothelium-denuded coronary arteries, performed isometric contractile force recordings and identified signaling molecules in coronary smooth muscle cells while estrogen was added. Estrogen relaxed arteries through endotheliumindependent mechanisms at the smooth muscle level. When arteries were pretreated with agents that impaired NO production, estrogen promoted contraction instead of dilatation. Reduction of superoxide $\left(\mathrm{O}_{2}^{-}\right)$radicals attenuated this contraction. The authors proposed a dual mechanism by which estrogen could act on the type 1 neuronal NOS isoform (nNOS), present in myocytes, leading to vasodilatation by NO production or vasoconstriction by $\mathrm{O}_{2}^{-}$release.

It is possible to question if the increase in the carotid resistance index could be deleterious to this group of patients. During the study, women did not report adverse reactions and high levels of estradiol were transitory. Studies such as $\mathrm{WHI}^{3,4}$ and HERS, ${ }^{21}$ which analyzed hormonal replacement effects on women with mean ages of 63 and 67 years, respectively, and the latter with coronary artery disease, showed a significant increase in the relative risk of stroke. Existing vascular damage when estrogen replacement therapy is initiated could facilitate carotid vasoconstriction and decrease cerebral blood flow.

The carotid resistance index and brachial diastolic flow velocity were the ultrasound parameters where the differences between healthy and unhealthy women could best be observed in our test. The acute response to nasal $17 \beta$-estradiol detected by Doppler ultrasound could differentiate, in a simple, noninvasive manner, healthy and unhealthy post-menopausal women. Currently, the gold standard to evaluate endothelial function is venous occlusion plethysmography, ${ }^{22}$ where arm blood flow is measured during infusions of increasing doses of acetylcholine into the brachial artery. This classical technique requires an intra-arterial injection of a vasodilatory substance. This exam is neither available nor specific for $17 \beta$ estradiol action.

\section{CONCLUSIONS}

Although this is a preliminary study with a small number of women, the acute response to nasal $17 \beta$-estradiol measured with Doppler ultrasound seemed able to differentiate women with normal and abnormal endothelial function in a simple, non-invasive manner.

The resistance index of the carotid artery and the diastolic flow velocity of brachial artery were the ultrasound parameters that best showed this difference: healthy women showed brachial vasodilatation, while unhealthy women displayed vasoconstriction at the carotid level. Vascular responses to estradiol were divergent between the groups.

The present test described here could be a practical alternative to evaluate potential vascular estrogen benefits and risks in postmenopausal women. We intend to perform additional studies with a larger number of women with specific pathologies to further identify estrogen vascular action according to endothelial status.

\section{ACKNOWLEDGEMENTS}

The authors wish to thank Dr. Peter Collins from the National Heart and Lung Institute, Imperial College, London, UK, for his comments about our study; Dr. Julio C.R. Pereira, Department of Epidemiology, Faculdade de Saúde Pública, USP, São Paulo, SP, Brazil, for statistical analysis and comments; and Drs. Amilcar B. Barbosa and Carlos Frederico Duarte da Rocha, Biology Graduate Program, State University of Rio de Janeiro for revising the manuscript.

The nasal formulation of $17 \beta$-estradiol was a generous gift of Servier Laboratórios of Brazil.

Laboratórios Sergio Franco generously performed serum determinations of $17 \beta$-estradiol.

\section{RESUMO}

Clapauch R, Mattos TM, Uchoa HBMP, Ferreira ASR, Bonisson VG, Lopes EL, Nascimento ICS, Bouskela E. Uso do Doppler vascular para detectar o efeito agudo do estradiol em mulheres na pós-menopausa. Clinics. 2007;62(6):673-8.

OBJETIVO: Descrever um teste simples e prático para avaliar o efeito vascular agudo do estradiol em mulheres saudáveis e não-saudáveis na menopausa.

INTRODUÇÃO: O estradiol atua no endotélio promovendo vasodilatação através de mecanismos genômicos e nãogenômicos e esta ação pode estar prejudicada em morbidades como diabetes mellitus, hipertensão, tabagismo e obesidade. 
MÉTODOS: Dezenove mulheres na pós-menopausa (9 saudáveis e 10 com dois ou mais dos fatores acima), com idade e tempo de menopausa semelhantes foram examinadas por Doppler vascular. O índice de resistência e as velocidades de fluxo sistólico e diastólico foram medidos nas artérias braquial e carótida, em condições basais e 20 min após a administração de uma preparação nasal de estradiol, disponível comercialmente, que atinge 1200 a $1500 \mathrm{pg} / \mathrm{ml}$ no soro, entre 10 e $30 \mathrm{~min}$ após a aplicação. Os níveis séricos de estradiol foram determinados $30 \mathrm{~min}$ após a aplicação nasal.

RESULTADOS: O índice de resistência da artéria carótida aumentou em 14,2\% (vasoconstricção) após o estradiol no grupo não-saudável, partindo da média \pm SE de $0,56 \pm 0,016$ para $0,64 \pm 0,05$ ( $\mathrm{p}=0,033)$ e não se modificou nas mulheres saudáveis. A velocidade de fluxo diastólico da artéria braquial aumentou 19,7\% (vasodilatação) nas mulheres saudáveis, partindo de $16,2 \pm 1,93$ para $19,4 \pm 0,64 \mathrm{~cm} / \mathrm{s}$ $(\mathrm{p}=0,046)$ e não apresentou alteração nas não saudáveis. Os níveis de estradiol foram semelhantes nos dois grupos.

DISCUSSÃO: Nas mulheres saudáveis na menopausa houve vasodilatação da artéria braquial e nas não-saudáveis vasoconstricção na artéria carótida. A resposta vascular ao estradiol foi divergente entre os grupos estudados.

CONCLUSÃO: O teste com estradiol agudo, associado ao Doppler vascular, parecem diferenciar, de forma simples e nãoinvasiva, mulheres com função endotelial normal e anormal.

UNITERMOS: Terapia de reposição hormonal. Estrogênio. Endotélio vascular. Vasodilatação. Vasoconstricção.

\section{REFERENCES}

1. Bush TL, Barrett-Connor E, Cowan LD, Criqui MH, Wallace RB, Suchindran $\mathrm{CM}$ et al. Cardiovascular mortality and noncontraceptive use of estrogen in women: results from the Lipid Research Clinics Program Follow-up Study. Circulation.1987;75:1102-9.

2. Grodstein F, Stampfer MJ, Colditz GA, Willett WC, Manson JE, Joffe M et al. Postmenopausal hormone therapy and mortality. N Engl J Med.1997;336:1769-75.

3. Rossouw JE, Anderson GL, Prentice RL, LaCroix AZ, Kooperberg C, Stefanick ML et al. Risks and benefits of estrogen plus progestin in healthy postmenopausal women: principal results From the Women's Health Initiative randomized controlled trial. JAMA.2002;288:321-333.

4. Anderson GL, Limacher M, Assaf AR, Bassford T, Beresford SA, Black $\mathrm{H}$ et al. Effects of conjugated equine estrogen in postmenopausal women with hysterectomy: the Women's Health Initiative randomized controlled trial. JAMA.2004;291:1701-12.

5. Clarkson TB, Appt SE. Controversies about HRT - lessons from monkey models. Maturitas.2005;51:64-74.

6. Clarkson TB, Anthony MS, Klein KP. Hormone replacement therapy and coronary artery atherosclerosis: the monkey model. Br J Obstet Gynaecol.1996;103(Suppl. 13):53-7.

7. Clarkson TB. The new conundrum: do estrogens have any cardiovascular benefits.Int J Fertil.2002;47:61-8.

8. Holm P, Andersen HL, Andersen MR, Erhardtsen E, Stender S. The direct antiatherogenic effect of estrogen is present, absent, or reversed, depending on the state of the arterial endothelium. A time course study in cholesterolclamped rabbits.Circulation.1999;100:1727-33.

9. Maturana MA, Irigoyen MC, Spritzer PM. Menopause, estrogens, and endothelial dysfunction: current concepts. Clinics.2007;62:77-86.

10. Guetta V, Quyyumi AA, Prasad A, Panza JA, Waclawiw M, Cannon RO. The role of nitric oxide in coronary vascular effects of estrogen in postmenopausal women. Circulation.1997;96:2795-801.

11. Florian M, Lu Y, Angle M, Magder S. Estrogen induced changes in Aktdependent activation of endothelial nitric oxide synthase and vasodilation. Steroids.2004;69:637-45.
12. Han G, Yu X, Lu L, Li S, Ma H, Zhu S et al. Estrogen receptor alpha mediates acute potassium channel stimulation in human coronary artery smooth muscle cells. J Pharmacol Exp Ther.2006;316:1025-30.

13. Barrett-Connor E, Giardina EG, Gitt AK, Gudat U, Steinberg HO, Tschoepe D. Women and heart disease: the role of diabetes and hyperglycemia. Arch Intern Med.2004;164:934-42.

14. Thorand B, Baumert J, Döring A, Schneider A, Chambless L, Löwel H et al. Association of cardiovascular risk factors with markers of endothelial dysfunction in middle-aged men and women. Results from the MONICA KORA Augsburg Study. Thromb Haemost.2006;95:134-41.

15. Ardigo D, Franzini L, Valtuena S, Monti LD, Reaven GM, Ivana Zavaroni I. Relation of plasma insulin levels to forearm flow-mediated dilatation in healthy volunteers. Am J Cardiol.2006;97:1250- 4.

16. Dooley M, Spencer CM, Ormrod D. Estradiol-intranasal: a review of its use in the management of menopause. Drugs.2001;61:2243-62

17. Zegura B, Keber I, Sebestjen M, Borko E.Orally and transdermally replaced estradiol improves endothelial function equally in middle- aged women after surgical menopause. Am J Obstet Gynecol.2003;188:1291-1296.

18. Acar M, Cevrioglu AS, Haktanir A, Demirel R, Albayrak R, Degirmenci $\mathrm{B}$ et al. Effect of Aerodiolâ administration on cerebral blood flow in postmenopausal women. Maturitas.2005; 52:127-133.

19. Lima SM, Aldrighi JM, Consolim-Colombo FM, Mansur Ade P, Rubira MC, Krieger EM et al. Acute administration of 17-beta estradiol improves endothelium - dependent vasodilation in postmenopausal women. Maturitas 2005; 50:266-274.

20. White RE, Han G, Dimitropoulou C, Zhu S, Miyake K, Fulton D et al Estrogen-induced contraction of coronary arteries is mediated by superoxide generated in vascular smooth muscle. Am J Physiol Heart Circ Physiol 2005; 289:H1468-75.

21. Hulley S, Grady D, Bush T, Furberg C, Herrington D, Riggs B et al. Heart and Estrogen/Progestin Replacement Study (HERS) Research Group. JAMA 1998;280:605-613.

22. Wilkinson IB, Webb DJ. Venous occlusion plethysmography in cardiovascular research: methodology and clinical applications. Br J Clin Pharmacol 2001;52:631-46. 